\title{
EARLY GROWTH OF COFFEE PLANTS AND SOIL FERTILITY PROPERTIES IN RESPONSE TO COFFEE HUSK APPLICATION
}

\author{
José Ricardo Mantovani ${ }^{1}$, Deyvid Wilker de Paula², Tiago Teruel Rezende ${ }^{3}$, \\ Adriano Bortolotti da Silva ${ }^{4}$, Paula Cristina Castro Andrade ${ }^{5}$, Paulo Roberto Côrrea Landgraf ${ }^{6}$
}

(Received: May 06, 2018; accepted: June 13, 2018)

\begin{abstract}
Coffee processing generates large amounts of husk, which can be used as organic fertilizer if technical criteria are considered. This study investigated the effect of coffee husk, applied to or incorporated into the soil, on soil fertility properties, early crop growth and nutrient accumulation in coffee plants. The experiment analyzed coffee plants in a greenhouse in pots, in randomized blocks, in a $5 \times 2$ factorial arrangement plus a control treatment, with four replicates. The treatments consisted of the combination of five coffee husk rates $\left(3.5 ; 7 ; 14 ; 28\right.$, and $\left.56 \mathrm{t} \mathrm{ha}^{-1}\right)$, applied in two forms: spread on the surface or incorporated into the soil, plus the control treatment, without husk application. Portions of $7 \mathrm{dm}^{3}$ soil were blended with lime, phosphate fertilizer, as well as coffee husk rates in the treatments with residue incorporation, and incubated for 30 days. Thereafter, one coffee seedling per plot was planted, the coffee husk rates were applied on the soil surface for the treatments without residue incorporation, and the plants were left to grow for 180 days. Coffee husk applied to or incorporated into the soil surface increases the $\mathrm{K}$ and organic matter contents of the soil, intensifies the early growth of coffee plants and accelerates $\mathrm{N}$ and $\mathrm{K}$ accumulation in the plant shoots. The application of coffee husk on the surface is more indicated than its incorporation into the soil, and the best rate at coffee planting is equivalent to $20 \mathrm{t} \mathrm{ha}^{-1}$.
\end{abstract}

Index terms: Coffea arabica, organic fertilization, organic waste, nutrient, potassium.

\section{CRESCIMENTO INICIAL DO CAFEEIRO E ATRIBUTOS DE FERTILIDADE DO SOLO COM APLICAÇÃO DE CASCA DE CAFÉ}

RESUMO: No beneficiamento do café são geradas grandes quantidades de casca, e o seu uso como adubo orgânico deve seguir critérios técnicos. Objetivou-se avaliar o efeito da casca de café, aplicada na superfície ou incorporada ao solo, em atributos de fertilidade do solo, no crescimento inicial e no acúmulo de nutrientes no cafeeiro. $\mathrm{O}$ experimento foi conduzido em casa-de-vegetação, em vasos, em delineamento em blocos casualizados, em esquema fatorial $5 \times 2$, um tratamento controle, e 4 repetições. Os tratamentos foram constituídos pela combinação de 5 doses de casca de café, equivalentes a 3,5; 7; 14; 28 e 56 t $\mathrm{ha}^{-1}$, aplicadas de 2 formas diferentes: na superfície ou incorporada no solo, além do controle, sem aplicação da casca. Porções de $7 \mathrm{dm}^{3}$ de solo receberam calcário e adubo fosfatado, além das doses de casca de café, nos tratamentos com a incorporação do resíduo, e foram submetidas à incubação por 30 dias. A seguir, foi efetuado transplantio de uma muda de cafeeiro por vaso, aplicação das doses de casca de café na superfície do solo, e o experimento foi conduzido por 180 dias. A aplicação da casca de café na superfície ou incorporada aumenta os teores de K e de matéria orgânica do solo, o crescimento inicial do cafeeiro e o acúmulo de N e K na parte aérea das plantas. A aplicação da casca de café na superfície é mais indicada do que a incorporação desse resíduo orgânico no solo, e a melhor dose no transplantio do cafeeiro é equivalente a $20 \mathrm{tha}^{-1}$.

Termos para indexação: Coffea arabica, adubação orgânica, resíduo orgânico, nutriente, potássio.

\section{INTRODUCTION}

Brazil is the world's leading coffee producer, and the crop is essential for the Brazilian economy, especially for the Southern region of the state of Minas Gerais, which has the highest domestic output (CONAB, 2017).

Coffee processing generates high residue quantities, one of which is the coffee cherry husk, a spin-off from the manufacturing of dryprocessed coffees (ZOCA et al., 2014; GARCIA and BIANCHI, 2015; MENEGHELLI et al., 2016).

The husk: grain proportion in terms of weight, is approximately $1: 1$, i.e., in each growing season an equal quantity of processed coffee and of husk is generated (MATIELLO et al., 2010; ASSIS et al., 2011; FERNANDES et al., 2013). Thus, in the growing seasons of 2017, the production of $44,970,000$ bags of processed coffee in Brazil (CONAB, 2017) may have generated approximately 2.7 million tons of coffee husk, of which approximately 820 thousand tons in the South and Midwest regions of Minas Gerais. Accordingly, there is a need to find alternative uses for this organic waste, to prevent environmental pollution problems (ZOCA et al., 2014; PESSOA et al., 2015).

Coffee husk can be used as animal feed (CARVALHO et al., 2011; OLIVO et al., 2017); to

1,2,3,4,5,6 José do Rosário Vellano University/Unifenas - Campus Alfenas - Agrarian Sciences Center - Cx. P. 23 - 37.130-000 Alfenas - MG - mantovanijr@yahoo.com, deyvid@cooxupe.com.br, tiagorezende@unifenas.br, adriano.silva@unifenas.br, paulaufop@yahoo.com.br, paulo.landgraf@unifenas.br

Coffee Science, Lavras, v. 13, n. 3, p. 356 - 364, jul./sep. 2018 
extract antioxidant compounds, used in the food, cosmetic and pharmaceutical industries (GARCIA and BIANCHI, 2015); as bedding in confinement facilities of animals (MATIELLO et al., 2010); and for power generation by direct burning, in industrial furnaces or in coffee bean dryers (SATER et al., 2011). However, for being a source of nutrients, in particular of $\mathrm{K}$ (HIGASHIKAWA; SILVA; BETTIOL, 2010), it is largely used in agriculture, as a substrate component for seedling production (ASSIS et al., 2011), in organic compost (SILVA et al., 2015), or mainly as organic fertilizer of coffee plants (FIDALSKI and CHAVES, 2010; FERNANDES et al., 2013).

However, for coffee cultivation, particularly at transplanting, there is no consensus on neither adequate coffee husk rates and about the best form of applying this residue, be it applied on or incorporated into the soil. The official recommendations of liming and fertilization for the state of São Paulo and Minas Gerais mention that coffee husk should be applied in the planting furrow of coffee (RAIJ et al., 1997; CFSEMG., 1999); while there is also information that organic residues should be spread on the soil surface (MATIELLO et al., 2010).

This study aimed to evaluate the effect of coffee husk, applied on the soil surface or incorporated into it, on soil fertility properties and on the early growth and nutrient accumulation of coffee plants.

\section{MATERIAL AND METHODS}

The experiment was carried out in a greenhouse, with coffee cultivated in pots, in Alfenas, Minas Gerais, from September 2014 through July 2015. A soil sample of approximately $400 \mathrm{dm}^{3}$ with clay texture from the surface layer $(0-$ $20 \mathrm{~cm}$ ) was analyzed, and the results of the initial routine chemical (SILVA, 2009) and particle-size analysis (CAMARGO et al., 2009) are presented in Table 1.

The experiment was arranged in randomized blocks, in a $5 \times 2$ factorial arrangement, with one control treatment and four replicates, resulting in a total of 44 experimental units (pots). The treatments consisted of combinations of five coffee husk rates $\left(12.3 ; 24.6 ; 49.2 ; 98.4 ; 196.6 \mathrm{~g} \mathrm{pot}^{-1}\right)$, equivalent, based on surface area of each pot $\left(352.39 \mathrm{~cm}^{2}\right)$ and in the area corresponding to 1 ha $\left(10.000 \mathrm{~m}^{2}\right)$, to $3.5 ; 7 ; 14 ; 28$; and $56 \mathrm{t} \mathrm{ha}^{-1}$, with two application forms: spread on the soil surface or mixed with the soil volume of each pot, simulating an application in the planting furrow. In the control treatment, no organic fertilization with coffee husk was applied. The coffee rusk rates were defined according to the CFSEMG (1999). The pots used in the experiment had a capacity of $8 \mathrm{dm}^{3}$.

The coffee husk, a spin-off product of the processing of dry-processed coffees, was previously air-dried in the shadow and sampled to determine the moisture, $\mathrm{pH}$ and chemical composition, on a dry basis, as described by Tedesco et al. (1995) (Table 2).

Soil portions of $7 \mathrm{dm}^{3}$ were weighed, treated with dolomitic lime $(\mathrm{CaO}=39 \% ; \mathrm{MgO}=13 \%$; PRNT $=91 \%$ ), to raise the initial base saturation of the soil to $60 \%$ (CFSEMG, 1999); phosphate fertilizer, at a rate of $100 \mathrm{mg} \mathrm{P} \mathrm{dm}^{-3}$, as simple superphosphate; and with coffee husk rates, in the treatments with organic waste incorporation. After blending these inputs with each soil portion, these were filled in $8 \mathrm{dm}^{3}$ pots, moistened with distilled water to about $70 \%$ of the water-holding capacity, and incubated for 30 days. During incubation, the soil moisture of each pot was maintained at $70 \%$ of water-holding capacity by periodic weighing of the pots and replacement of the lost water.

At the end of incubation, the soil portions were removed from the pots, air-dried, and a sample of $0.2 \mathrm{dm}^{3}$ per pot was collected for routine analysis of the chemical properties (SILVA, 2009) and electrical conductivity, in a soil:distilled water extract at a 1:5 (v:v) ratio (RAIJ et al., 2001). After sampling, $6.8 \mathrm{dm}^{3}$ of soil was refilled into the pots, and one seedling of coffee cultivar Mundo Novo IAC 376-4 was planted per pot in Dezember 2014. At transplanting, the seedlings had the following mean characteristics: height $21 \mathrm{~cm}$; stem diameter $0.25 \mathrm{~cm}$; and 12 leaves.

After planting the coffee seedlings the coffee husk rates were applied to the surface of the pots, in the treatments of surface residue application. Thereafter, the soil of each pot was watered to $70 \%$ water-holding capacity, and the plants were left to grow for 180 days.

During the experiment, the soil moisture was maintained at approximately $70 \%$ of the water-holding capacity. At 30, 70 and 100 days after planting of the coffee seedlings $\mathrm{N}$ fertilization in the form of urea was applied. At each application, $100 \mathrm{~mL}$ solution containing 20 $\mathrm{mg} \mathrm{N} \mathrm{dm}{ }^{-3}$ was applied on the surface of all pots. No K was fertilized in the experiment. 
TABLE 1 - Chemical and particle-size characterization of the soil used in the experiment.

\begin{tabular}{|c|c|c|c|c|c|c|c|c|c|c|c|c|c|c|}
\hline $\mathrm{OM}$ & $\begin{array}{c}\mathrm{pH} \\
\mathrm{CaCl}_{2}\end{array}$ & P-Mehlich & $\mathrm{K}^{+}$ & $\mathrm{Ca}^{2+}$ & $\mathrm{Mg}^{2+}$ & $\mathrm{Al}^{3+}$ & $\mathrm{H}+\mathrm{Al}$ & $\mathrm{SB}$ & $\mathrm{T}$ & $\mathrm{V}$ & $\mathrm{m}$ & Sand & Silt & Clay \\
\hline $\mathrm{g} \mathrm{dm}^{-3}$ & & $\mathrm{mg} \mathrm{dm}^{-3}$ & & & $\mathrm{mr}$ & $\mathrm{nol}_{\mathrm{c}} \mathrm{c}$ & & & 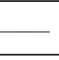 & $-\%$ & & & & ב \\
\hline 30 & 5,3 & 6 & 3,1 & 20 & 11 & 1 & 38 & 34 & 72 & 47 & 3 & 384 & 93 & 523 \\
\hline
\end{tabular}

OM - Organic matter; H+Al - potential acidity; SB - sum of bases; T - potential cation exchange capacity; V - base saturation; $\mathrm{m}-\mathrm{Al}^{3+}$ saturation

TABLE 2 - Moisture, $\mathrm{pH}$ and chemical composition on a dry basis of the coffee husk used in the experiment.

\begin{tabular}{|c|c|c|c|c|c|c|c|}
\hline Moisture & $\mathrm{pH}$ & C-org. & $\mathrm{N}$ & $\mathrm{C} / \mathrm{N}$ ratio & & & $\mathrm{K}$ \\
\hline$\%$ & \multicolumn{4}{|c|}{$\mathrm{g} \mathrm{kg}^{-1}$} & \multicolumn{3}{|c|}{$\mathrm{g} \mathrm{kg}^{-1}$} \\
\hline 8,8 & 4,5 & 360,2 & 22,1 & $16 / 1$ & \multicolumn{2}{|c|}{0,7} & 27,3 \\
\hline $\mathrm{Ca}$ & $\mathrm{Mg}$ & S & B & $\mathrm{Cu}$ & $\mathrm{Fe}$ & $\mathrm{Mn}$ & $\mathrm{Zn}$ \\
\hline 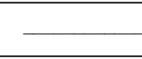 & $\mathrm{g} \mathrm{kg}^{-1}$ & 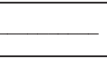 & & 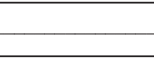 & \multicolumn{3}{|c|}{$\mathrm{mg} \mathrm{kg}^{-1}$} \\
\hline 3,4 & 1,1 & 1,7 & 27 & 31 & 238 & 42 & 13 \\
\hline
\end{tabular}

At crop, the plant height from the soil surface to the base of the apical bud was measured with a tape measure. Thereafter, the coffee plants were cut at the ground level of each pot, washed, dried to constant weight in a forced air circulation oven, ground, and the macronutrient and micronutrient contents were determined (TEDESCO et al., 1995). Nutrient accumulation in the coffee shoots was calculated as the product of the nutrient contents by the shoot dry matter yield of the coffee trees.

After the crop, in the treatments with coffee husk spread on the soil surface, the remaining husk was removed with a spatula, dried in a forced air circulation oven and weighed to determine the decomposition rate of this organic waste. Then, with a spatula and a ruler, soil was taken from the layers $0-5,5-10$ and $10-20 \mathrm{~cm}$ of each pot for routine chemical analysis (SILVA, 2009).

The results of soil chemical attributes and parameters evaluated in the plants were subjected to analysis of variance, the Tukey test for mean comparison $(p<0.05)$ and to polynomial regression. In the treatments of residue surface application, the statistical analysis of the results regarding $\mathrm{K}$ and organic matter contents were carried out for each layer, since a comparison between layers was not the objective of this study. For these analyses, we used the statistical program AgroEstat (BARBOSA; MALDONADO JÚNIOR, 2015).

\section{RESULTS AND DISCUSSION}

There was interaction between the factors studied (coffee husk rates and application forms) on the chemical attributes evaluated in soil. The incorporation of coffee husk rates into the soil altered $(\mathrm{p}<0.01)$ the $\mathrm{K}$, organic matter contents and values of electrical conductivity of the soil.

There was a linear increase in $\mathrm{K}^{+}$and organic matter contents and in the values of electrical conductivity (EC) of the soil after incorporation of coffee husk rates (Figure 1A, 1B and 1C). In relation to $\mathrm{K}^{+}$, the soil content ranged from 3.3 to $20.4 \mathrm{mmol}_{\mathrm{c}} \mathrm{dm}^{-3}$, and was six times higher in the treatment with the highest coffee husk rate than in the control.

Soil $\mathrm{K}^{+}$contents above $5 \mathrm{mmol}_{\mathrm{c}} \mathrm{dm}^{-3}$ are considered very high for coffee, and ${ }^{c}$ under this condition, no $\mathrm{K}$ fertilization is required at seedling planting, nor in the first and second year after planting (CFSEMG, 1999). Thus, soil incorporation of an amount of $56 \mathrm{t} \mathrm{ha}^{-1}$ of coffee husk increased the soil $\mathrm{K}$ content 4 -fold in relation to the lower limit of the class of very high content, established by the soil fertility commission of the state of Minas Gerais CFSEMG (1999).

On average $94 \%$ of the K supplied to the soil with the incorporation of the doses of coffee husk were detected by soil analysis, in the samples collected 30 days after incubation of the organic waste with soil, demonstrating the rapid $\mathrm{K}$ release from coffee husk. This can be explained by the fact that $\mathrm{K}$ does not participate in the structure of organic compounds, and is maintained in the ionic form in plant tissues and in organic waste (SODRÉ et al., 2012). 

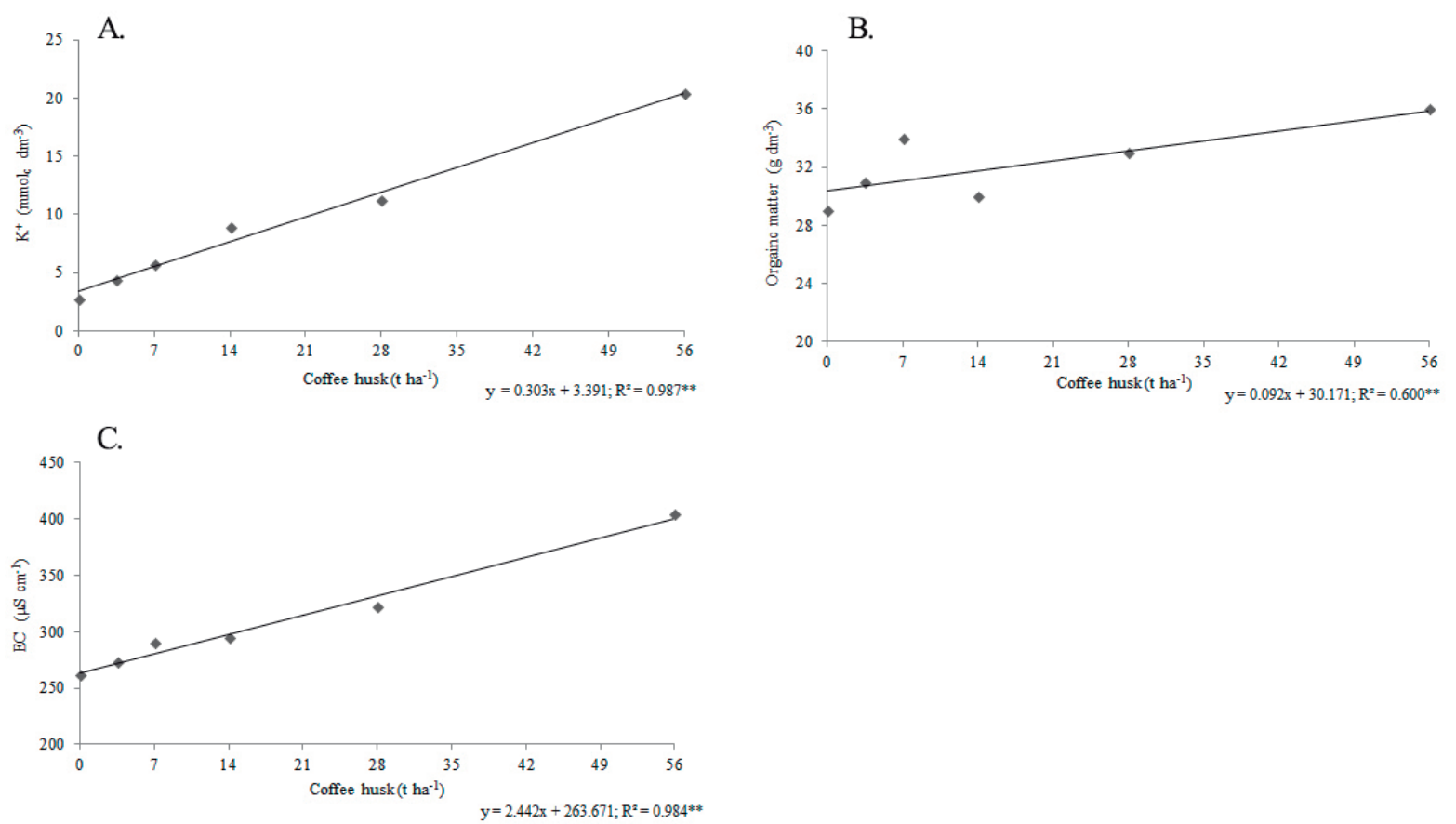

FIGURE 1 - Contents of K (A), organic matter (B) and electrical conductivity of the soil (C) in response to incorporated coffee husk rates.

Similar results were reported by Zoca et al. (2014), in a greenhouse experiment using soil columns and rates of different residues from coffee processing, including the husk of coffee cherry. The authors found that $\mathrm{K}$ release from these residues was high $(>90 \%)$, and that they could be used as a substitute for mineral $\mathrm{K}$ fertilizer. In a greenhouse experiment, Sodré et al. (2012) also found a linear increase in the soil $\mathrm{K}^{+}$ content after application extract rates of cocoa pod husk. For producing coffee plants, Fernandes et al. (2013) found that annual applications of $20 \mathrm{t} \mathrm{ha}^{-1}$ of coffee husk can offset mineral $\mathrm{K}$ fertilization by up to $100 \%$.

Very high nutrient contents in the soil can induce nutritional imbalances. In the case of $\mathrm{K}^{+}$, the result is a decrease in the plant uptake of other cations such as $\mathrm{Ca}^{2+}$ and $\mathrm{Mg}^{2+}$, due to competition for absorption sites, aside from favoring the displacement of $\mathrm{Mg}^{2+}$ from the exchange complex, thereby aggravating $\mathrm{K}$ losses by leaching (DAMATTO JÚNIOR et al., 2006). The incidence of diseases such as brown eye spot and rust in coffee plants is also favored by nutritional imbalance, with very high $\mathrm{K}$ contents in soil and plant leaves, due to coffee husk applications (SANTOS et al., 2008). Excessive $\mathrm{K}^{+}$contents in the soil can also promote the dispersion of clay particles, reducing the porosity and affecting other soil physical properties (UYEDA et al., 2013).
The contents of soil organic matter ranged from 30.2 to $35.3 \mathrm{~g} \mathrm{dm}^{-3}$ in the treatments in which coffee husk was incorporated into the soil, and the resulting increase was $17 \%$ compared to the treatments with highest and lowest applications (Figure 1B). Of the quantity of organic $\mathrm{C}$ added to the soil in the coffee husk rates, a mean $32 \%$ was found to remain in the soil as a soil organic matter component, where it was detected by chemical analysis. This result can be explained by the high lignin content contained in this organic waste (ZOCA et al., 2014), which hampers decomposition and humus formation in the soil.

Souza et al. (2014) found no changes in the organic matter content of the $0-20 \mathrm{~cm}$ soil layer after five years of surface applications of rates up to $36 \mathrm{t} \mathrm{ha}^{-1}$ of waste generated by the guava processing industry, consisting basically of seeds of the fruit. In the $0-5 \mathrm{~cm}$ layer of an area of producing coffee plants, Silva et al. (2015) found a linear increase in organic $\mathrm{C}$ content, and consequently of soil organic matter, in response to surface applications of organic compound containing coffee husk.

After incorporating coffee husk rates into the soil, the EC ranged from 264 to $400 \mu \mathrm{s} \mathrm{cm}^{-1}$, and in the treatment fertilized with the highest organic residue rate the soil EC was 1.5 times 
higher than in the control treatment. The high ion concentrations, e.g., of $\mathrm{K}^{+}$, in coffee husk explain the increase in soil EC by the application of this organic waste (CARMO et al., 2016). Similar results were reported by Higaskikawa, Silva and Bettiol (2010); Pinheiro, Silva and Lima (2014) and Carmo, Lima and Silva (2016), who also observed an increase in the soil EC in response to coffee husk application.

In view of the increase in the $\mathrm{EC}$ of the soil, Higaskikawa, Silva and Bettiol (2010) warned that the use of coffee husk in agriculture requires a careful management of the rates to be applied to crops. However, in this study the soil EC values were below the critical range of $750-3.490 \mu \mathrm{s} \mathrm{cm}^{-1}$, mentioned by Carmo, Lima and Silva (2016) as detrimental to plant growth.

The $\mathrm{pH}$ values and potential acidity $(\mathrm{H}+\mathrm{Al})$, and the contents of P-Mehlich, $\mathrm{Ca}^{2+}$ and $\mathrm{Mg}^{2+}$ in the soil were not altered ( $\left.\mathrm{p}>0.05\right)$ with the incorporation of coffee husk rates into the soil. The mean values of the $\mathrm{pH}$ in $\mathrm{CaCl}_{2}$ and $\mathrm{H}+\mathrm{Al}$ in the experiment were 5.8 and $24.7 \mathrm{mmolc} \mathrm{dm}^{-3}$, respectively. The mean nutrient contents were, respectively, $31 \mathrm{mg} \mathrm{dm}^{-3} ; 36$ and $15 \mathrm{mmol}_{\mathrm{c}} \mathrm{dm}^{-3}$, which are classified as, respectively, medium, good and good values, based on CFSEMG (1999), for the implementation of a coffee plantation on clayey soil. These results can be explained by the low P, $\mathrm{Ca}$ and $\mathrm{Mg}$ contents of coffee husk (Table 2). Similar results were found by Fidalski and Chaves (2010) and by Fernandes et al. (2013).

In a field experiment with producing coffee plants, Fidalski and Chaves (2010) found that two surface applications of $20 \mathrm{tha}^{-1}$ of coffee husk did not alter the contents of P-Mehlich, $\mathrm{Ca}^{2+}$ and $\mathrm{Mg}^{2+}$ in the soil in the $0-5 ; 5-10 ; 10-20$ and 20-40 cm layers. In a coffee plantation treated with surface applications of coffee husk for three consecutive growing seasons, Fernandes et al. (2013) found no alterations in the $\mathrm{pH}$ and P-resin, $\mathrm{Ca}^{2+}$, and $\mathrm{Mg}^{2+}$ contents in the soil surface layer $(0-20 \mathrm{~cm})$.

The application of coffee husk rates on the surface altered $(p<0.01)$ the $K$ and organic matter contents of the soil, but did not influence ( $p>$ 0.05 ) the $\mathrm{pH}$ and $\mathrm{H}+\mathrm{Al}$ values, and the $\mathrm{P}, \mathrm{Ca}$ and $\mathrm{Mg}$ contents in the 0-5, 5-10 and 10-20 cm layers.

There was an increase in $\mathrm{K}$ contents in the soil in the $0-5,5-10$, and $10-20 \mathrm{~cm}$ layers, with the application of coffee husk rates on the surface (Figure 2A). The $\mathrm{K}$ contents in the 0-5, 5-10 and $10-20 \mathrm{~cm}$ layers were $0.8-19.8,0.6-13.4$, and 0.9 $-7.9 \mathrm{mmolc} \mathrm{dm}^{-3}$, respectively. With this, after 180 days of coffee husk applications to the surface, the increases in $\mathrm{K}$ contents in these layers were, respectively, $24.8 ; 22.3$ and 8.8 -fold, compared to the control treated with the highest organic waste rate (equivalent to $56 \mathrm{t} \mathrm{ha}^{-1}$ ).

Induced by the application of residues from coffee processing, Zoca et al. (2014) also stated an increase in the soil $\mathrm{K}$ content in the different layers. According to these authors, the potassium applied in these residues did not prevent $\mathrm{K}$ leaching losses.

The contents of soil organic matter, in the 0-5 cm layer, increased linearly with the surface application of the coffee husk rates, and the resulting increase was 1.1-fold compared to the extreme treatments with applications of 0 and $56 \mathrm{tha}^{-1}$ (Figure $2 \mathrm{~B}$ ). In the other evaluated layers (5-10 and $10-20 \mathrm{~cm}$ ) the organic matter content of the soil fertilized with coffee husk on the surface remained unchanged, with mean contents of 26 and $25 \mathrm{~g} \mathrm{dm}^{-3}$, respectively.

After 180 days of organic residue applications on the soil surface, the decomposition of coffee husk was, on average, $70 \%$ and $50 \%$, respectively, in the soils treated with the two lowest and the two highest coffee husk rates. Zoca et al. (2014) reported decomposition of 20 to $60 \%$ of the coffee cherry husk applied to the soil surface, and the lowest decomposition rates were also observed in response to the highest residue applications.

No effect was observed of interaction between the factors studied (coffee husk rates and application forms) on the parameters evaluated in coffee plants: plant height; dry matter yield and nutrients accumulated in shoots. With this, both the surface application and the incorporation of coffee husk rates in the soil resulted in a quadratic effect in height and dry matter yield of coffee shoots, and the highest values were obtained in response to the estimated rates of 42 and $49 \mathrm{tha}^{-1}$, respectively (Figure 3A and 3B).

The application of a rate of $20 \mathrm{t} \mathrm{ha}^{-1}$ would result in coffee plants with a height of $60 \mathrm{~cm}$ and shoot dry matter of $60 \mathrm{~g}$, corresponding to 94 and $89 \%$ of the maximum values, and 18 and $31 \%$ higher than the control, respectively. Thus, rates above $20 \mathrm{tha}^{-1}$ of coffee husk induced practically no increase in the early growth of coffee plants.

In producing coffee plants, Fidalski and Chaves (2010) observed an increase in plant height, number of branches, canopy volume, and yield in response to coffee husk applications. 

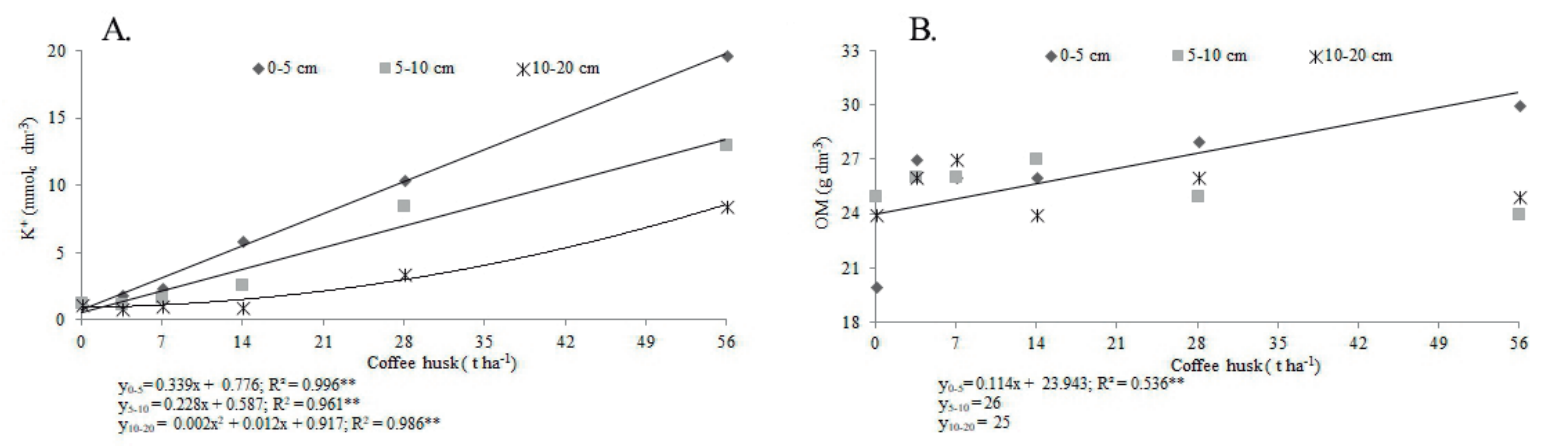

FIGURE 2 - Contents of $\mathrm{K}$ (A), and organic matter (B), in the $0-5 ; 5-10 ; 10-20 \mathrm{~cm}$ layers, in response to the application of coffee husk rates on the soil surface.
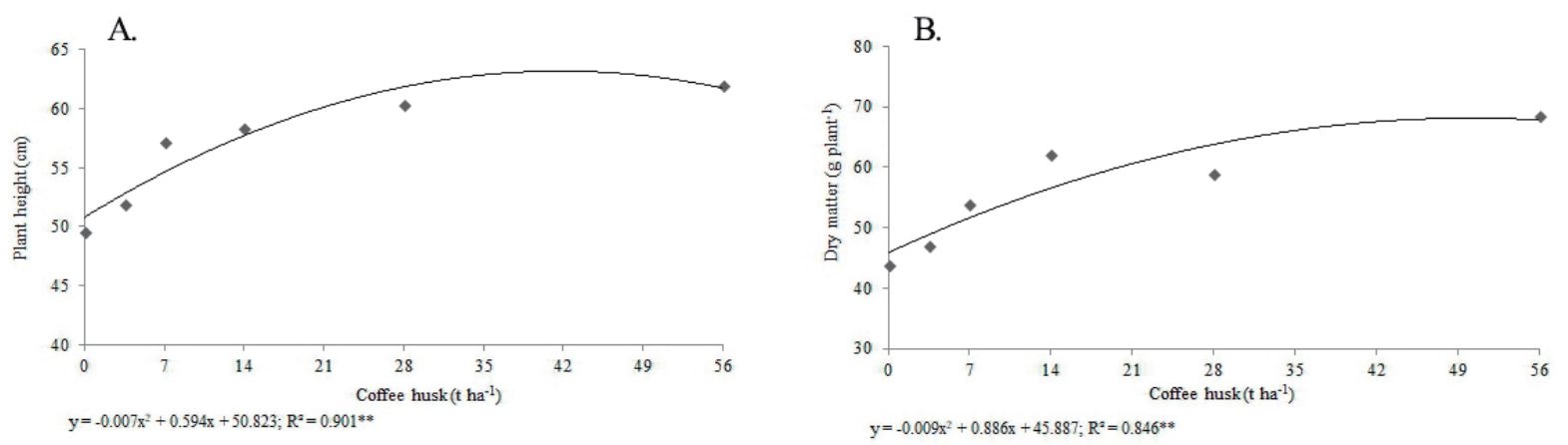

FIGURE 3 - Height (A) and shoot dry matter production (B) of coffee plants in response to coffee husk rates.

An increase in coffee yield was also reported by Fernandes et al (2013) due to the use of organic waste.

In relation to the husk application forms, the soil surface application resulted in coffee plants with taller height and higher shoot dry matter yield, with mean increases of 20 and $14 \%$, respectively (Figures $4 \mathrm{~A}$ and $4 \mathrm{~B}$ ). The immobilization of soil $\mathrm{N}$ and the higher temperature and soil moisture variations, which probably occurred in the treatments with coffee husk incorporation, possibly explain these results. Thus, the coffee husk application of the surface may possibly contribute to the maintenance of soil moisture and, consequently, favor the growth of the coffee plants.

In an experiment with coffee plants cultivated in pots, Santos, Souza and Alves (2003) found that the incorporation of crop residues of maize shoots in the soil reduced the leaf area and plant height of coffee trees, whereas in the treatments where these residues were applied to the soil surface, the early growth of coffee plants was intensified. The authors used the same explanations as in this study to justify these results.
In a coffee area intercropped with tree species and fruit trees, Souza et al. (2017) found lower temperature and higher humidity, compared to the treatment in which this practice was not used (monoculture, under full sun), where the former conditions favored the plant development.

There was an increase in the cumulative $\mathrm{N}$ and $\mathrm{K}$ quantities in coffee shoots in response to the application of coffee husk rates, both on the soil surface or incorporated into it, and the increases were 1.5 and 2.1 -fold when compared with the control treated with the highest organic waste rate (Figures 5A and 5B).

The cumulative $\mathrm{Ca}$ and $\mathrm{Mg}$ coffee shoot contents were not altered $(p>0.05)$ by coffee husk application, with mean contents of 310 and $108 \mathrm{mg}$ plant $^{-1}$, respectively (Figure 5C). Therefore, in this experiment no decrease in $\mathrm{Ca}$ and $\mathrm{Mg}$ plant uptake was observed, due to the presence of very high $\mathrm{K}$ contents in the soil. The initial $\mathrm{Ca}$ and $\mathrm{Mg}$ contents in the soil (20 and $11 \mathrm{mmol} \mathrm{dm}^{-3}$ respectively), classified as good content, according to CFSEMG (1999), and the use of dolomitic lime $(\mathrm{CaO}=$ $39 \%$; $\mathrm{MgO}=13 \%$ ) may explain the absence of competitive inhibition among the cations $\mathrm{K}^{+}, \mathrm{Ca}^{2+}$ and $\mathrm{Mg}^{2+}$. 
A.

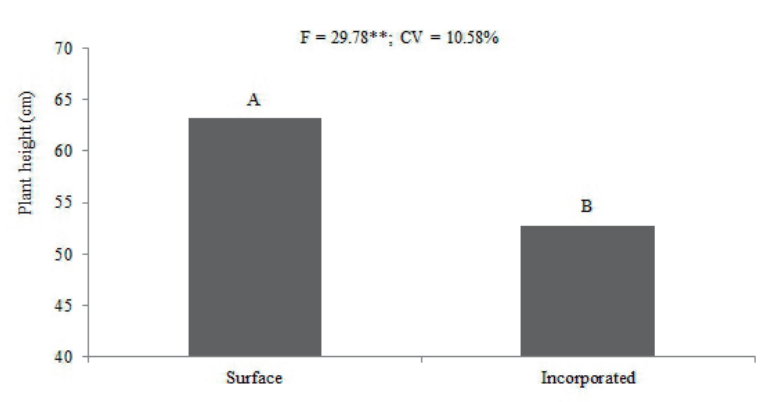

B.

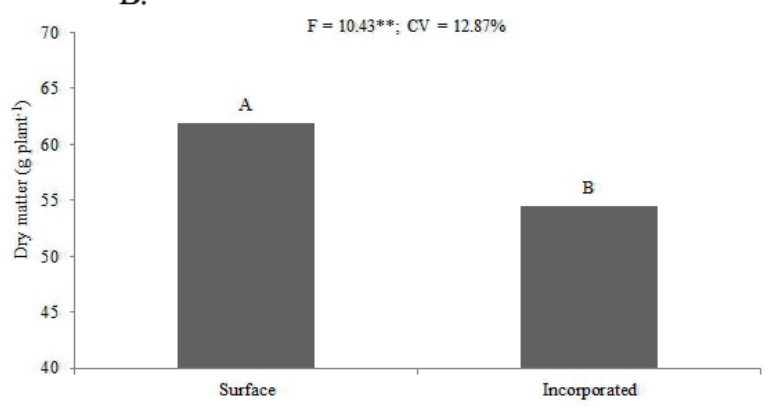

FIGURE 4 - Plant height (A) and shoot dry matter production (B) of coffee plants in response to coffee husk application on the soil surface or incorporated into it.
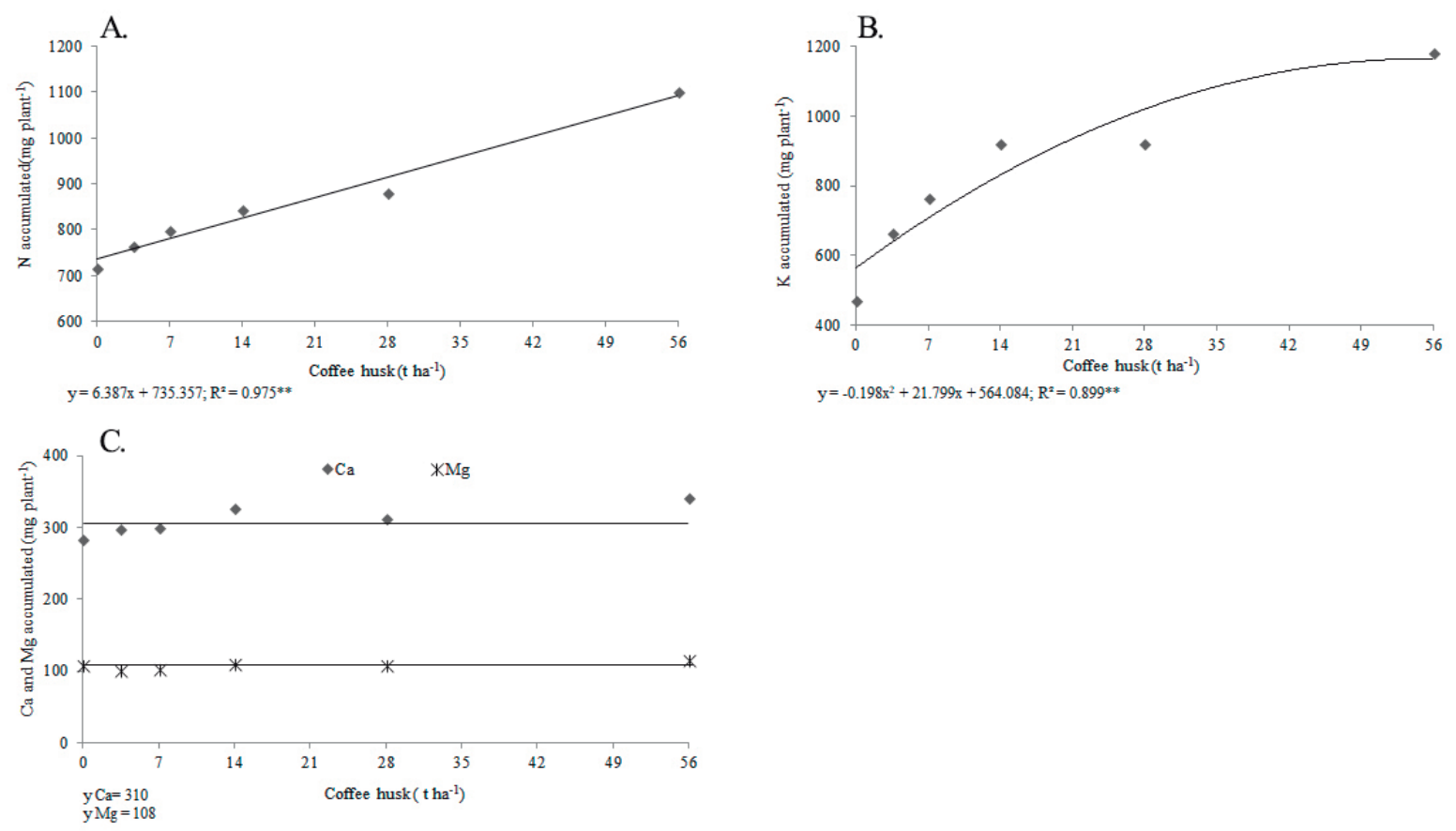

FIGURE 5 - Accumulated quantities of $\mathrm{N}$ (A) (B), $\mathrm{K}, \mathrm{Ca}$, and $\mathrm{Mg}(\mathrm{C})$ in coffee shoots in response to coffee husk rates.

The coffee husk rates did not change ( $p>$ 0.05 ) the quantities of $\mathrm{P}, \mathrm{S}, \mathrm{B}, \mathrm{Cu}, \mathrm{Fe}, \mathrm{Mn}$, and $\mathrm{Zn}$ accumulated in the coffee shoots, and the mean values were, respectively, $56 ; 41 ; 1.4 ; 0.3 ; 4.1$; and $2.4 \mathrm{mg} \mathrm{plant}^{-1}$. The low contents of these nutrients in coffee husk explain this lack of response.

The cumulative quantities of $\mathrm{N}$ and $\mathrm{K}$ in the coffee shoots were not influenced ( $p>0.05$ ) by the application form of coffee husk, be it spread on or incorporated into the soil (Figure 6). In the case of $\mathrm{K}$, the release of the nutrient from coffee husk is independent of the application form of the residue. In relation to $\mathrm{N}$, the possible immobilization by soil microorganisms, in the treatments of coffee husk incorporation, probably occurred only during the first weeks after coffee planting, and was followed by $\mathrm{N}$ mineralization. Therefore, at the end of the experiment, $\mathrm{N}$ accumulation in the plant shoots was similar to that of the treatments in which the organic residue was applied on the surface. 

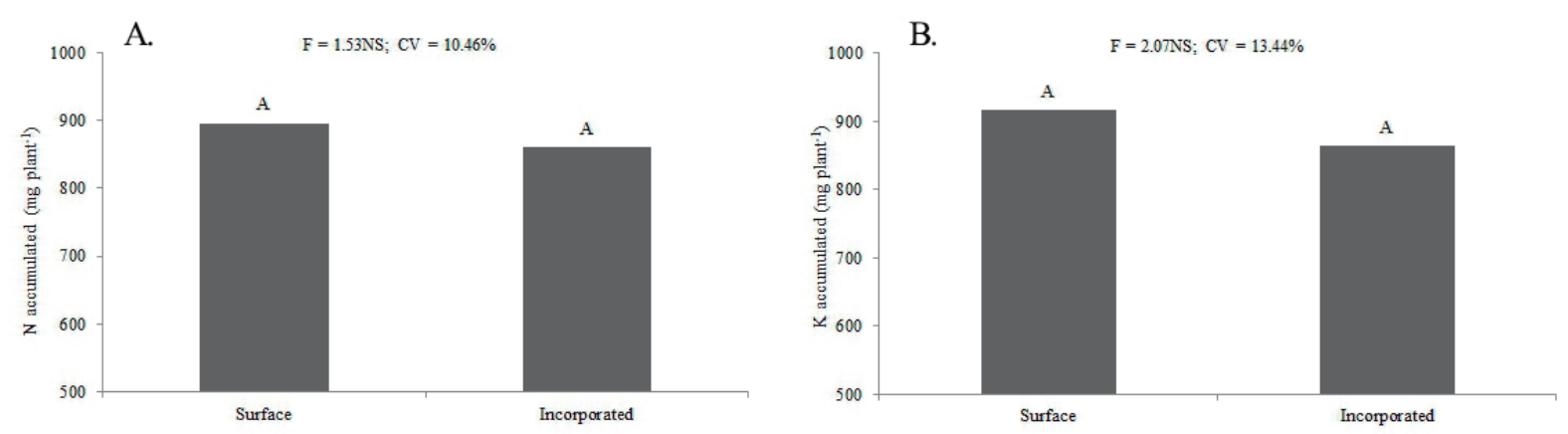

FIGURE 6 - Accumulated quantities of $\mathrm{N}(\mathrm{A})$ and $\mathrm{K}(\mathrm{B})$ in coffee shoots in response to coffee husk application on the soil surface or incorporated into it.

\section{CONCLUSIONS}

Coffee husk applied to or incorporated into the soil surface increases the contents of $\mathrm{K}$ and organic matter, the early growth of coffee plants and $\mathrm{N}$ and $\mathrm{K}$ accumulation in the plant shoots;

The application of coffee husk on the soil surface is more indicated than the incorporation of organic waste into the soil, and the best rate at coffee planting is equivalent to $20 \mathrm{tha}^{-1}$.

\section{ACKNOWLEDGMENTS}

The authors wish to thank the Conselho Nacional de Desenvolvimento Científico e Tecnológico (CNPq/Pibic) for the scientific initiation scholarship and are indebted to the Fundação de Amparo à Pesquisa de Minas Gerais (Fapemig) for the financial support.

\section{REFERENCES}

ASSIS, A. M. et al. Cultivo de orquídea em substratos à base de casca de café. Bragantia, Campinas, v. 70, n. 3, p. 544-549, Apr/June. 2011.

BARBOSA, J. C.; MALDONADO JÚNIOR, W. Experimentação agronômica e AgroEstat: sistema para análises estatísticas de ensaios agronômicos. Jaboticabal: Multipress, 2015. 396p.

CAMARGO, O. A. et al. Métodos de análise química, mineralógica e física de solos do Instituto Agronômico de Campinas. Campinas: Instituto Agronômico, 2009. 77p. Boletim Técnico, 106.

CARMO, D. L.; LIMA, L. B.; SILVA, C. A. Soil fertility and electrical conductivity affected by organic wastes and nutriente inputs. Revista Brasileira de Ciência do Solo, Viçosa, v. 40. 2016.
CARVALHO, P. L. O. et al. Sticky coffee hull silage on the feeding of growing and finishing pigs. Revista Brasileira de Zootecnia, Viçosa, v. 40, n. 2, p. 343351, Feb. 2011.

COMISSÃO DE FERTILIDADE DO SOLO DO ESTADO DE MINAS GERAIS - CFSEMG. Recomendações para o uso de corretivos e fertilizantes em Minas Gerais, $5^{\text {a }}$ aproximação. Viçosa: Ed. UFV, 1999. 359p.

COMPANHIA NACIONAL DE ABASTECIMENTO. Acompanhamento da safra brasileira café safra 2017: quarto levantamento, dezembro/2017. Brasília, 2017.

DAMATTO JUNIOR, E. R. et al. Alterações em propriedades de solo adubado com doses de composto orgânico sob cultivo de bananeira. Revista Brasileira de Fruticultura, Jaboticabal, v. 28, n. 3, p. 546-549, Sept/Dec. 2006.

FERNANDES, A. L. T. et al. Redução da adubação mineral do cafeeiro arábica com a utilização de palha de café. Coffee Science, Lavras, v. 8, n. 3, p. 324-336, July/Sept. 2013.

FIDALSKI, J.; CHAVES, J. C. D. Resposta do cafeeiro (Coffea arabica L.) IAPAR-59 à aplicação superficial de resíduos orgânicos em um latossolo vermelho distrófico típico. Coffee Science, Lavras, v. 5, n. 1, p. 75-86, Jan/Apr. 2010.

GARCIA, L. R. P.; BIANCHI, V. L. D. Capacidade antioxidante em resíduos da indústria cafeeira. Brazilian Journal of Food Technology, Campinas, v. 18, n. 4, p. 307-313, Oct/Dec. 2015. 
HIGASHIKAWA F. T.; SILVA, C. A.; BETTIOL, W. Chemical and physical properties of organic residues. Revista Brasileira de Ciência do Solo, Viçosa, v. 34, n. 5, p. 1743-1752, 2010.

MATIELLO, J. B. et al. Cutura do café no Brasil: manual de recomendações. Rio de Janeiro; Varginha: Fundação PROCAFÉ, 2010. 542 p.

MENEGHELLI, C. M. et al. Resíduo da secagem dos grãos de café como substrato alternativo em mudas de café conilon. Coffee Science, Lavras, v. 11, n. 3, p. 329-334, July/Sept. 2016.

OLIVO, P. M. et al. Assessing the nutritional value of agroindustrial co-products and feed through chemical composition, in vitro digestibility, and gas production techinique. Acta Scientiarum Animal Sciences, Maringá, v. 39, n. 3, p. 289-295, July/Sept. 2017.

PESSOA, R. S. et al. Solubilization of potassium from alternative rocks by humic and citric acids and coffee husk. Ciência e Agrotecnologia, Lavras, v. 39, n. 6, p. 553-564, Nov/Dec. 2015.

PINHEIRO, G. L.; SILVA, C. A.; LIMA, J. M. Soluble carbon in oxisol under the effect of organic residue rates. Revista Brasileira de Ciência do Solo, Viçosa, v. 38, n. 3, p. 810-820, May/June. 2014.

RAIJ, B. V. et al. (Ed.). Recomendações de adubação e calagem para o Estado de São Paulo. 2 ed. rev. atual. Campinas: Instituto Agronômico/Fundação IAC, 1997. 285p. Boletim Técnico, 100.

RAIJ, B. V. et al. Análise química para avaliação da fertilidade de solos tropicais. Campinas: Instituto Agronômico, 2001. 285p.

SANTOS, C. C.; SOUZA, I. F.; ALVES, L. W. R. Efeitos de restos culturais de milho sobre o crescimento de plantas de cafeeiro (Coffea arabica L.). Ciência e Agrotecnologia, Lavras, v. 27, n. 5, p. 991-1001, Sept/ Oct. 2003.

SANTOS, F. S. et al. Adubação orgânica, nutrição e progresso de cercosporiose e ferrugem-do-cafeeiro. Pesquisa Agropecuária Brasileira, Brasília, v. 43, n. 7, p. 783-791, July. 2008.
SATER, O. et al. Estudo comparativo de carbonização de resíduos agrícolas e florestais visando à substituição de lenha no processo de secagem de grãos de café. Revista Ceres, Viçosa, v. 58, n. 6, p. 717-722, Nov/ Dec. 2011.

SILVA, F. C. Manual de análises químicas de solos, plantas e fertilizantes. 2ed. rev atual. Brasília: Embrapa Informação Tecnológica, 2009. 627p.

SILVA, V. M. et al. Estoques de carbono e nitrogênio e densidade do solo em sistemas de adubação orgânica de café conilon. Revista Brasileira de Ciência do Solo, Viçosa, v. 39, n. 5, p. 1436-1444, Sept/Oct. 2015.

SODRÉ, G. A. et al. Extrato da casca do fruto do cacaueiro como fertilizante potássico no crescimento de mudas de cacaueiro. Revista Brasileira de Fruticultura, Jaboticabal, v. 34, n. 3, p. 881-887, July/ Sept. 2012.

SOUZA, G. S. et al. Soil phisico-hydraulic properties under organic conilon coffee intercropped with tree and fruit species. Pesquisa Agropecuária Brasileira, Brasília, v. 52, n. 7, p. 539-547, July. 2017.

SOUZA, H. A. et al. Uso fertilizante do subproduto da agroindústria processadora de goiabas. I - Atributos químicos do solo. Revista Brasileira de Fruticultura, Jaboticabal, v. 36, n. 3, p. 713-724, July/Sept. 2014.

TEDESCO, M. J. et al. Análise de solo, plantas e outros materiais. 2.ed. Porto Alegre: Universidade Federal do Rio Grande do Sul, 1995. 147p.

UYEDA, C. A. et al. Influence of vinasse application in hydraulic conductivity of three soils. Engenharia Agrícola, Jaboticabal, v. 33, n. 4, p. 689-698, July/Aug. 2013.

ZOCA, S. M. et al. Coffee processing residues as a soil potassium amendment. Journal of Recycling of Organic Waste in Agriculture, Isfahan, v. 3, n. 1, 155165, Jan/Mar. 2014. 